\title{
Correction to: Flavagline analog FL3 induces cell cycle arrest in urothelial carcinoma cell of the bladder by inhibiting the Akt/PHB interaction to activate the GADD45a pathway
}

\author{
Gangjun Yuan ${ }^{1,2+}$, Xin Chen ${ }^{1,2+}$, Zhuowei Liu ${ }^{2 \dagger}$, Wensu Wei ${ }^{1,2}$, Qinghai Shu ${ }^{3}$, Hussein Abou-Hamdan ${ }^{4}$, Lijuan Jiang ${ }^{1}$, \\ Xiangdong Li ${ }^{1}$, Rixin Chen ${ }^{2}$, Laurent Désaubry ${ }^{4,5^{*}}$, Fangjian Zhou ${ }^{1,2^{*}}$ and Dan Xie ${ }^{1^{*}}$
}

\section{Correction to: J Exp Clin Cancer Res 37, 21 (2018) https://doi.org/10.1186/s13046-018-0695-5}

Following publication of the original article [1], the authors identified minor errors in image-typesetting in Fig. 4; specifically in Fig. 4c.

The corrected figure is given below. The correction does not have any effect on the results or conclusions of the paper.

\section{Author details}

${ }^{1}$ State Key Laboratory of Oncology in South China; Collaborative Innovation Center for Cancer Medicine, Sun Yat-sen University Cancer Center, Guangzhou 510060, China. ${ }^{2}$ Department of Urology, Sun Yat-sen University Cancer Center, Guangzhou, China. ${ }^{3}$ School of Material Science and Engineering, Beijing Institute of Technology, Beijing, China. ${ }^{4}$ Therapeutic Innovation Laboratory, UMR7200, CNRS/University of Strasbourg, Strasbourg, France. ${ }^{5}$ Sino-French Joint Lab of Food Nutrition/Safety and Medicinal Chemistry, College of Biotechnology, Tianjin University of Science and Technology, Tianjin, China.
Published online: 30 March 2021

\section{Reference}

1. Yuan G, Chen X, Liu Z, et al. Flavagline analog FL3 induces cell cycle arrest in urothelial carcinoma cell of the bladder by inhibiting the Akt/PHB interaction to activate the GADD45a pathway. J Exp Clin Cancer Res. 2018 37:21 https://doi.org/10.1186/s13046-018-0695-5.

The original article can be found online at https://doi.org/10.1186/s13046-01 8-0695-5.

*Correspondence: desaubry@unistra.fr; zhoufj@sysucc.org.cn;

xiedan@sysucc.org.cn

${ }^{\dagger}$ Gangjun Yuan, Xin Chen and Zhuowei Liu contributed equally to this work.

${ }^{4}$ Therapeutic Innovation Laboratory, UMR7200, CNRS/University of

Strasbourg, Strasbourg, France

'State Key Laboratory of Oncology in South China; Collaborative Innovation

Center for Cancer Medicine, Sun Yat-sen University Cancer Center, Guangzhou 510060, China

Full list of author information is available at the end of the article

C C The Author(s). 2021 Open Access This article is licensed under a Creative Commons Attribution 4.0 International License, which permits use, sharing, adaptation, distribution and reproduction in any medium or format, as long as you give appropriate credit to the original author(s) and the source, provide a link to the Creative Commons licence, and indicate if changes were made. The images or other third party material in this article are included in the article's Creative Commons licence, unless indicated otherwise in a credit line to the material. If material is not included in the article's Creative Commons licence and your intended use is not permitted by statutory regulation or exceeds the permitted use, you will need to obtain permission directly from the copyright holder. To view a copy of this licence, visit http://creativecommons.org/licenses/by/4.0/. The Creative Commons Public Domain Dedication waiver (http://creativecommons.org/publicdomain/zero/1.0/) applies to the data made available in this article, unless otherwise stated in a credit line to the data. 
a
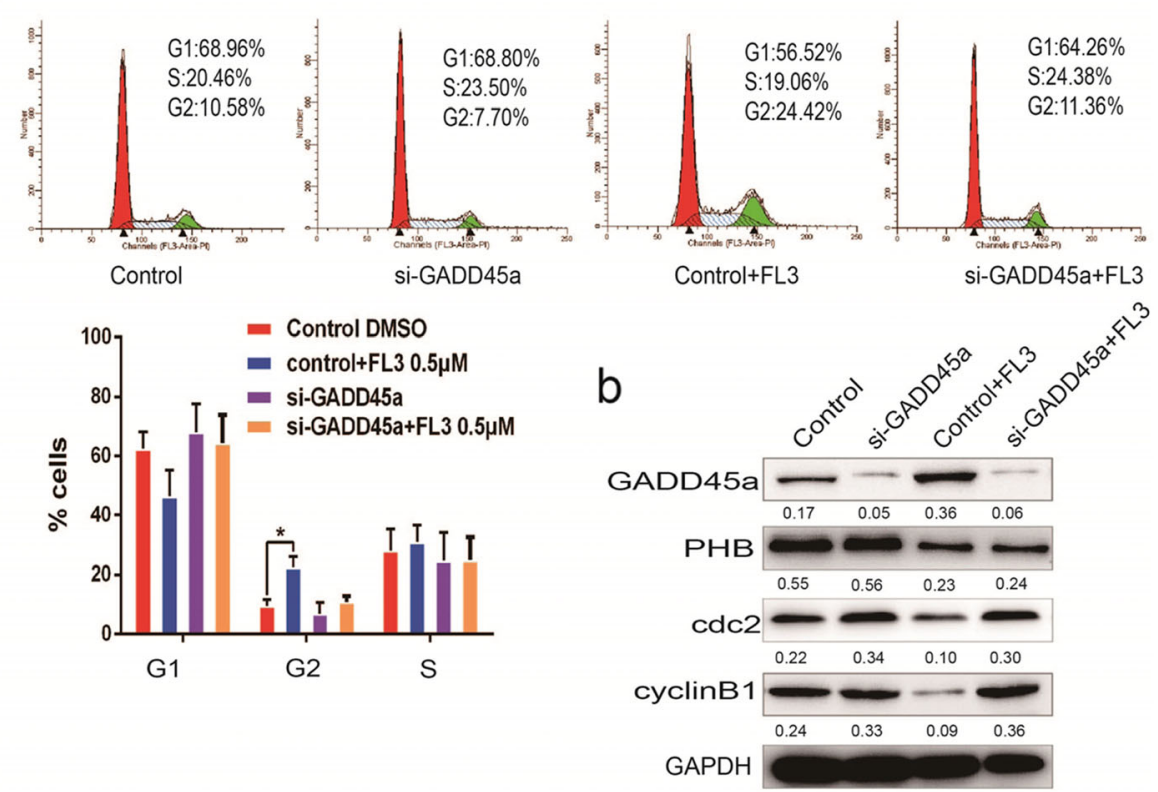

C
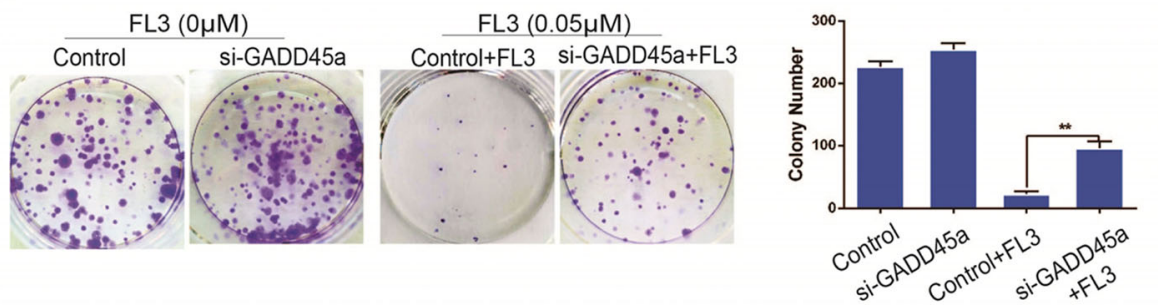

Fig. 4 Repression of GADD45a decreases the inhibitory effect of FL3 on cell cycle progression. a Flow cytometry assay was performed in T24 cells to measure the effect of FL3 on the cell cycle distribution in the presence or absence of siGADD45a-RNA. The percentage of cells in each phase was shown in the histograms; data represent the mean \pm SD of three independent experiments, ${ }^{*} P<0.05$ indicates a significant difference. $\mathbf{b}$ Total cell lysates from indicated T24 cells (up panel) were harvested and subjected to Western blot analysis with the indicated proteins (left panel). c Cell colony formation experiments were performed to measure the inhibitory effect of FL3 on cell proliferation of T24 cells in the presence or absence of GADD45a. Histograms represent the mean \pm SD numbers of colonies of three independent experiments. ${ }^{* *} P<0.01$ indicates significance 